\title{
Hyperthyroidism in pregnancy: evidence and hypothesis in fetal programming and development
}

\author{
Stine Linding Andersen ${ }^{1,2}$ and Stig Andersen ${ }^{2,3}$ \\ 'Department of Clinical Biochemistry, Aalborg University Hospital, Aalborg, Denmark \\ 2Department of Clinical Medicine, Aalborg University, Aalborg, Denmark \\ ${ }^{3}$ Department of Geriatrics, Aalborg University Hospital, Aalborg, Denmark
}

Correspondence should be addressed to S L Andersen: stine.a@rn.dk

\begin{abstract}
The management of hyperthyroidism in pregnant patients has been a topic of raised clinical awareness for decades. It is a strong recommendation that overt hyperthyroidism of Graves' disease in pregnant women should be treated to prevent complications. The consequences of hyperthyroidism in pregnancy are less studied than hypothyroidism, and a literature review illustrates that the main burden of evidence to support current clinical guidance emerges from early observations of severe complications in Graves' disease patients suffering from untreated hyperthyroidism in the pregnancy. On the other hand, the more long-term consequences in children born to mothers with hyperthyroidism are less clear. A hypothesis of fetal programming by maternal hyperthyroidism implies that excessive levels of maternal thyroid hormones impair fetal growth and development. Evidence from experimental studies provides clues on such mechanisms and report adverse developmental abnormalities in the fetal brain and other organs. Only few human studies addressed developmental outcomes in children born to mothers with hyperthyroidism and did not consistently support an association. In contrast, large observational human studies performed within the last decade substantiate a risk of teratogenic side effects to the use of antithyroid drugs in early pregnancy. Thus, scientific and clinical practice are challenged by the distinct role of the various exposures associated with Graves' disease including the hyperthyroidism per se, the treatment, and thyroid autoimmunity. More basic and clinical studies are needed to extend knowledge on the effects of each exposure, on the potential interaction between exposures and with other determinants, and on the underlying mechanisms.
\end{abstract}

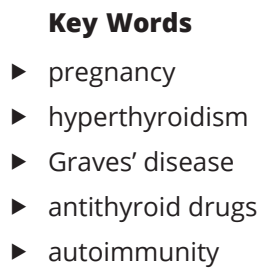

Endocrine Connections (2021) 10, R77-R86

\section{Introduction}

Hyperthyroidism is the clinical state that results from an excessive production of thyroid hormones in the thyroid gland $(1,2)$. It is a signature of the disease that the incidence of the different subtypes of hyperthyroidism varies with age (3). While toxic nodular goiter is the predominant cause of hyperthyroidism after the age of 50 years, the predominant cause of hyperthyroidism in patients younger than 50 years of age is Graves' disease (GD) (3).
Since GD predominantly occurs in female patients and in the reproductive time span, the management of the disease should consider the patient's reproductive history and the possibility of a current or future pregnancy $(1,2)$.

GD is an autoimmune disease caused by alterations in the immune system, and a key pathophysiological mechanism is the production of TSH-receptor autoantibodies (TRAb) (4). The disease was first described in 
the 19th century, and considerations on the management in pregnant women, specifically, can be ascertained from the beginning of the 20th century with a main concern about adverse pregnancy outcomes in women suffering from severe, untreated hyperthyroidism (5).

The use of antithyroid drugs (ATDs) for the treatment of hyperthyroidism was introduced in clinical practice in the 1940s and is currently the recommended treatment for the hyperthyroidism of GD in pregnant women (6). Clinical guidelines indisputably state that overt hyperthyroidism caused by GD in pregnant women should be treated to prevent maternal and fetal complications, however, the management is challenged by the potential risk of severe side effects associated with the treatment $(1,2)$. Furthermore, a pertinent question is on the role of thyroid autoimmunity. Thus, the determination of causal factors for outcome of a pregnancy and offspring development in women suffering from the hyperthyroidism of GD is complex and hitherto not clarified in detail.

In this review, we explore outcomes of hyperthyroidism in pregnancy with a focus on the underlying mechanisms and different exposures associated with the disease (hyperthyroidism per se, antithyroid drug treatment, and thyroid autoimmunity). We describe the hypothesis of fetal programming by maternal hyperthyroidism and supporting evidence from experimental and human studies, and we discuss methodological aspects and implications for scientific and clinical practice.

\section{The hypothesis of fetal programming}

Fetal programming is a concept within reproductive epidemiology that links exposures during fetal life with the later development of disease in the offspring. It has been described in relation to different maternal diseases and different mechanisms have been proposed, however, the overall hypothesis is analogous irrespective of the specific exposure and outcome (7). The concept is also known as 'fetal origin of adult diseases' (8), and the basic idea is that disturbances during fetal life can cause permanent alterations in the offspring that at a later point in time might predispose to the development of adverse outcomes. Many aspects are yet to be clarified considering the mechanisms, but growing evidence is linking the concept to epigenetic alterations (9). Different study designs are used to investigate the hypothesis. Experimental evidence is a classic determinant of causality as brought forward by Bradford Hill in the 1960s (10). In addition to such results, the main burden of evidence develops from observational human studies.
The determination of causality in observational studies is a difficult task, and it is a challenge to distinguish the exposure of interest from other prenatal exposures and from the role of postnatal exposures during development (7).

Considering fetal programming by maternal thyroid disease, the role of thyroid hormones during fetal development is a key mechanism (7). Thyroid hormones are important developmental factors (11). The fetal thyroid gland is increasingly able to synthesize thyroid hormones in the second half of a pregnancy, which emphasizes the importance of maternal thyroid hormones in the early pregnancy. Furthermore, the importance of maternal thyroid hormones in later pregnancy after the onset of fetal thyroid hormone production is evident from the measurement of thyroxine (T4) in cord blood from newborns with a defect in thyroid hormone synthesis (12). Thus, maternal thyroid function remains important to the fetus throughout the pregnancy. The transport of thyroid hormones from the mother to the fetus during a pregnancy and physiological alterations affecting maternal thyroid function should be considered. In the early pregnancy, the pregnancy hormone human chorionic gonadotropin (hCG) stimulates the maternal thyroid gland to an increased production of thyroid hormone, potentially balancing the extra need of thyroid hormones to supply both the mother and the fetus (13). Yet, another mechanism in the early pregnancy that tends to balance the effect of hCG is the type 3 deiodinase (DIO3) in placenta (13). This enzyme inactivates thyroid hormones by catalyzing the conversion of $\mathrm{T} 4$ to reverse T3 (rT3) and T3 to T2. Activity of DIO3 in placenta is apparent from the early pregnancy weeks in rats and in humans and is evident from the high rT3/T3 ratio seen in pregnant women (13). The activity of DIO3 is considered part of the reason why athyreotic women need a 50\% increase in their Levothyroxine dose by the time they become pregnant (14). Thus, the activity of DIO3 is likely to explain the higher maternal TSH in the early pregnancy prior to the hCG-peak $(13,15)$. In line with this thought, patients with DIO3 containing hemangiomas present with consumptive hypothyroidism and a high rT3/ T3-ratio (16). These findings suggest a delicate balance under strict hormonal control and propose clinically important impact of slight imbalance.

Considering outcomes of maternal thyroid disease in pregnancy, the focus has especially been turned to hypothyroidism. The hypothesis of fetal programming by maternal hypothyroidism is biological plausible from experimental evidence and from the description of cretinism with profound mental and physical deficits in

This work is licensed under a Creative Commons Attribution-NonCommercial-NoDerivatives 4.0 International License.ifica com at $04 / 26 / 2023 \quad 08: 47: 59 \mathrm{Am}$ 
children born to mothers with severe hypothyroidism caused by iodine deficiency (7). Consequently, clinical guidelines unanimously state that overt hypothyroidism in pregnant women should be treated, whereas the management of smaller abnormalities in thyroid function such as subclinical hypothyroidism, and the entity of isolated low T4 (hypothyroxinemia) is unclarified $(1,17)$. Turning from lack of maternal thyroid hormone to excess, it is similarly a strong and consistent recommendation that overt hyperthyroidism caused by GD should be treated in pregnant women $(1,2)$. However, the hypothesis of fetal programming by maternal hyperthyroidism (Fig. 1) has gained less attention (1). It is likely that the association between thyroid activity and adverse outcomes of pregnancy and child development is u-shaped. Such dependency is seen for other prenatal exposures for example, maternal hemoglobin concentration in pregnancy and outcomes of pregnancy as well as environmental factors for example, iodine and iron intake (18). This offers a path to follow for describing the influence of maternal thyroid dysfunction on pregnancy outcomes.

\section{Hyperthyroidism and fetal brain development}

Thyroid hormones regulate numerous processes during early brain development including neuronal proliferation, migration, differentiation, synaptogenesis, and myelination (19). In addition to the development of brain structures, they also play a role in the regulation of the neurochemical environment. It sounds reasonable that the lack of thyroid hormones might disturb these processes, whereas it is less clear how an excessive production of thyroid hormones associated with hyperthyroidism could affect fetal development. We searched the PubMed database for original, experimental studies on fetal outcomes of maternal hyperthyroidism in pregnancy up until October 1, 2020, and this search identified 52 publications. By contrast, a search for hypothyroidism identified 247 publication, which illustrates the predominant focus on this entity.
After review of the search results, we identified nine studies $(20,21,22,23,24,25,26,27,28)$ that investigated the impact of maternal hyperthyroidism on fetal brain development in experimental animals (Table 1). Notably, all the studies reported one or more abnormal findings in the offspring after exposure to maternal hyperthyroidism. However, the findings were diverse. All studies used T4 for the induction of maternal hyperthyroidism, but the method of T4 administration differed between the studies and the timing of outcome assessment in the offspring ranged from gestational day 21 up until the third postnatal month (Table 1). It is beyond the scope of this review to describe and discuss details regarding the design and methodology of studies in experimental animals. However, some considerations seem important to highlight when interpreting and including evidence from experimental studies in a clinical context. First, the age of an experimental animal and the duration of a pregnancy are not interchangeable with humans $(29,30)$. Whereas the human pregnancy is on average 40 weeks, the length of a pregnancy is 22 days in rats and 19 days in mice (29). Furthermore, disparities exist regarding the postnatal age as compared to humans and among experimental animals, for example, rats and mice. Thus, the lifespan of laboratory rat is about 3 years, whereas it is about 2 years for laboratory mice (30). Considering these life spans in relation to human age, an age of $1 / 3 / 6$ months in rats approximate $9 / 15 / 18$ years of age in humans and an age of $1 / 3 / 6$ months in a mice approximate 14/23/34 years of age in humans (30). Secondly, the timing and duration of the various neurodevelopmental stages are not completely synchronous in humans and in experimental animals (29). Furthermore, the structural and functional properties of different brain regions and organs are not identical. For example, the placentas of humans and rats show anatomical similarities with a discoid shape and hemochorial type of fetal-maternal interface, however, disparities exist regarding the histological structure and the function of the yolk sac (31). Finally, important considerations are on the assessment of brain development in humans and in experimental animals, respectively (32).

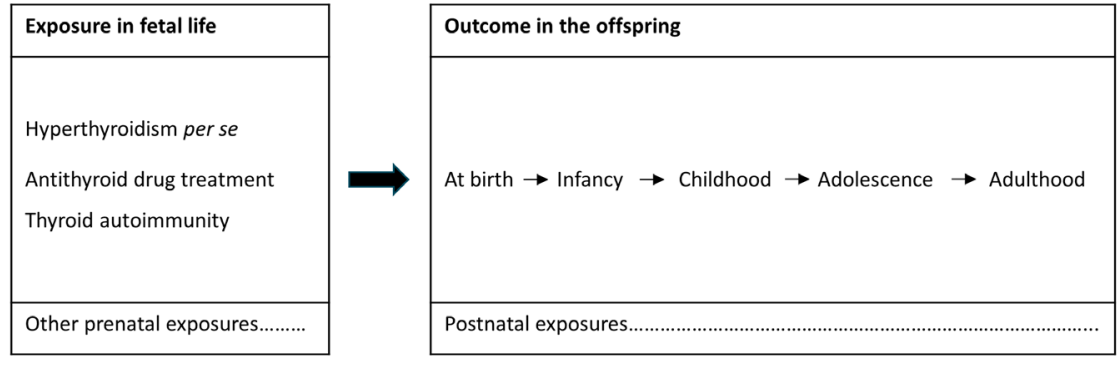

Figure 1

The hypothesis of fetal programming by maternal hyperthyroidism. https://ec.bioscientifica.com https://doi.org/10.1530/EC-20-0518 (c) 2021 The authors Published by Bioscientifica Ltd
This work is licensed under a Creative Commons Attribution-NonCommercial-NoDerivatives 4.0 Internationab ficense.ifica . com at 04/26/2023 08:47:59AM 
Table 1 Experimental studies on maternal hyperthyroidism in pregnancy and brain development in the offspring.

\begin{tabular}{|c|c|c|c|c|c|}
\hline Author & Year & Animal & $\begin{array}{l}\text { Induction of } \\
\text { hyperthyroidism }\end{array}$ & $\begin{array}{l}\text { Outcome } \\
\text { assessment }\end{array}$ & Findings in the offspring \\
\hline Evans et al. (20) & 2002 & Rats & s.c. infusion (T4) & $\overline{\text { Gestational day } 21}$ & $\begin{array}{l}\text { Increased expression of different } \\
\text { neuronal cytoskeletal proteins in } \\
\text { the brain }\end{array}$ \\
\hline Zhang et al. (21) & 2008 & Rats & s.c. infusion (T4) & $\begin{array}{l}\text { Postnatal months } \\
1-3\end{array}$ & $\begin{array}{l}\text { Altered morphology of hippocampal } \\
\text { neurons and impaired ability to } \\
\text { cope with stress }\end{array}$ \\
\hline Zhang et al. (22) & 2010 & Rats & s.c. infusion (T4) & $\begin{array}{l}\text { Postnatal months } \\
1-3\end{array}$ & $\begin{array}{l}\text { Aberrant organization of } \\
\text { hypothalamic stress related regions } \\
\text { in the brain }\end{array}$ \\
\hline El-Bakry et al. (23) & 2010 & Rats & $\begin{array}{l}\text { Intragastric } \\
\text { administration (T4) }\end{array}$ & $\begin{array}{l}\text { Postnatal weeks } \\
1-3\end{array}$ & $\begin{array}{l}\text { Histopathological effects in different } \\
\text { brain regions and accelerated } \\
\text { skeletal features }\end{array}$ \\
\hline Ahmed et al. (24) & 2010 & Rats & $\begin{array}{l}\text { Intragastric } \\
\text { administration (T4) }\end{array}$ & $\begin{array}{l}\text { Postnatal weeks } \\
1-3\end{array}$ & $\begin{array}{l}\text { Increased excitability and synaptic } \\
\text { transmissions in cerebrum, } \\
\text { cerebellum and medulla oblongata }\end{array}$ \\
\hline Ahmed et al. (25) & 2012 & Rats & $\begin{array}{l}\text { Intragastric } \\
\text { administration (T4) }\end{array}$ & $\begin{array}{l}\text { Postnatal weeks } \\
1-3\end{array}$ & $\begin{array}{l}\text { Impaired development of neurons in } \\
\text { different brain regions and excess } \\
\text { oxidative stress }\end{array}$ \\
\hline Strobl et al. (26) & 2017 & Mice & $\begin{array}{l}\text { Intraperitoneal } \\
\text { administration (T4) }\end{array}$ & Postnatal day 18 & $\begin{array}{l}\text { Abnormal axons and synapses in } \\
\text { thalamocortical neurons and in } \\
\text { visual cortex }\end{array}$ \\
\hline $\begin{array}{l}\text { Laureano-Melo } \\
\text { et al. (27) }\end{array}$ & 2019 & Mice & s.c. infusion (T4) & Postnatal day 70 & $\begin{array}{l}\text { Alterations in hippocampal } \\
\text { serotonergic and GABAergic } \\
\text { systems and increased anxiolysis }\end{array}$ \\
\hline Salami et al. (28) & 2019 & Rats & $\begin{array}{l}\text { Added to drinking water } \\
\text { (T4) }\end{array}$ & $\begin{array}{l}\text { Postnatal days } 5 \text {, } \\
10,20\end{array}$ & $\begin{array}{l}\text { Increased expression of } \\
\text { hippocampal apolipoprotein D and } \\
\text { increased oxidative stress }\end{array}$ \\
\hline
\end{tabular}

T4, thyroxine.

A commonly used marker in humans is the intelligence quotient (IQ). It is a standardized measure based on a subset of tests (33). Alternative markers of brain development in humans include structural abnormalities in the brain assessed using for example brain scans of the child at a certain age (34). Furthermore, information on diagnosis of neurodevelopmental diseases in the child can be used as a proxy for impaired brain development (7). As opposed to this, the assessment of brain development in experimental animals such as rats and mice commonly relies on histopathological examination and evaluation of gene expression and in addition to these markers, the performance of the animal in different test (e.g. maze) can be evaluated (Table 1). However, no measure of brain development in an experimental animal directly translates to IQ in humans (32). Furthermore, it is important to notice that many methodological considerations exist when the role of maternal thyroid disease in relation to fetal brain development is assessed in humans and in an experimental design. In humans, the risk of confounding is a particular concern in observational designs (7), and in experimental animals it has recently been discussed that the currently available models may not be sensitive enough to detect the neurodevelopmental abnormalities associated with different degrees of abnormal maternal thyroid function (32).

Although the findings are diverse, evidence suggests that maternal hyperthyroidism in pregnancy may impair fetal brain development in experimental animals (Table 1) via alterations in the development and organization of neurons, in the neurochemical environment, and altered expression of different proteins in the brain. However, the human brain is more complex and slight developmental skewness may cause disturbances that are detectable in humans only.

So, what do we know from human studies about brain development in children born to mothers with hyperthyroidism? Few studies addressed outcomes of brain development in the child in relation to maternal hyperthyroidism. In contrast, the number of studies that addressed the association between insufficient levels of maternal thyroid hormones and child brain development is considerable $(1,17)$. A recent systematic review and meta-analysis identified nine observational studies on the association between maternal hyperthyroidism in pregnancy and neurodevelopmental diseases in 
the offspring including attention deficit hyperactivity disorder, autism spectrum disorder, epilepsy, and schizophrenia (35). Most of these studies were registerbased studies, which are typically large, but are hampered by the fact that the assessment of exposure in pregnancy is indirectly performed from hospital diagnoses and/or redeemed prescriptions of drugs. For each of the different outcomes, only two individual studies were included in a meta-analysis, and the combined measures showed a significant association between maternal hyperthyroidism and ADHD and epilepsy in the child (35). In another study (36), using a case-cohort design, the assessment of maternal hyperthyroidism was made from the measurement of thyroid function parameters in stored blood samples from the early pregnancy. In this study, a risk of epilepsy in the child was corroborated, but no association between maternal hyperthyroidism and ADHD in the child was seen (36). Notably, high circulating levels of thyroid hormones in patients with generalized resistance to thyroid hormone (mutation in the thyroid receptor $\beta$-gene) have been associated with a high occurrence of ADHD (37), providing a clue toward an association between hyperthyroidism and brain development. Furthermore, parallel observations in human and in rats have shown that fetal exposure to high maternal thyroid hormone levels is associated with persistent central resistance to thyroid hormones in adulthood, likely mediated via increased expression of the DIO3 in the brain (38). Hence, mechanisms of fetal programming may include offspring alterations in the hypothalamic-pituitary-thyroid hormone axis.

Other outcomes of human fetal neurodevelopmental (child IQ and brain scans) are similarly rarely investigated in relation to maternal hyperthyroidism in pregnancy, but studies within different birth cohorts have evaluated the association between levels of TSH and free T4 in pregnancy and child IQ as well as child cortex and gray matter volume $(33,34)$. The findings are not consistent, and many determinants are to be considered, but results provide clues of a possible $\mathrm{u}$-shaped association.

\section{Hyperthyroidism and other outcomes of fetal development}

The critical role of thyroid hormones during brain development is an important concern, but the consequences of a disturbance in maternal thyroid function in pregnancy may extend beyond fetal brain development. Thyroid hormones are developmental factors and regulate numerous processes in many organs. Considering the hypothesis of fetal programming by maternal hyperthyroidism (Fig. 1), one may speculate on other outcomes of fetal development that are not related to the brain. From the literature search, we identified seven experimental studies (Table 2) that evaluated outcomes of maternal hyperthyroidism in pregnancy in relation to the development of other organ systems in the offspring not related to brain development $(39,40,41,42$, $43,44,45)$. The studies were predominantly performed in rats, and the timing and type of outcome differed (Table 2). Thus, the studies assessed the development of genital organs, the cardiovascular system as well as bone and cartilage. Notably, all studies reported at least one abnormal finding, however, it appeared that some of the alterations were reversible for instance in the development of the bone (Table 2).

Considering human findings, only few studies investigated such other outcomes of fetal development. Studies from different birth cohorts have instigated blood pressure, BMI, total fat mass, and abdominal s.c. fat mass in children born to mothers with hyperthyroidism $(46,47$, 48). Overall, results did not point toward associations except that lower maternal TSH levels associated with lower child BMI, fat mass, and diastolic blood pressure in one of the cohorts, in which no association with clinically diagnosed hyperthyroidism was seen (46). On the other hand, maternal hyperthyroidism as well as hypothyroidism has been associated with alterations in maternal body weight (48). Thus, it is a methodological challenge to distinguish the role of maternal thyroid disease from other BMI-related factors in the evaluation of fetal outcomes.

\section{Hyperthyroidism and pregnancy complications}

From the experimental and human studies reviewed previously that addressed the role of maternal hyperthyroidism in pregnancy in relation to fetal brain development and the development of other organ systems, it seems as if the strong and consistent clinical recommendation on treatment of overt hyperthyroidism caused by GD in pregnant women relies on other determinants. Thus, the main concern related to hyperthyroidism in pregnant women and the recommendation for treatment relate to the risk of complications during the pregnancy and/or at birth of the child and to a lesser extent on the evidence considering more long-term outcomes in the child.

This work is licensed under a Creative Commons Attribution-NonCommercial-NoDerivatives 4.0 Internationab f ficense.ifica com at 04/26/2023 08:47:59Am 
It has been clinically recognized for more than a century that maternal hyperthyroidism can seriously complicate a pregnancy (5). The evidence in humans arises from clinical case studies, and the description of pregnancy complications in women referred to a hospital for the management of Graves' hyperthyroidism in pregnancy. These reports from 1929 and onwards have substantiated a focus on the adverse effects of untreated or insufficiently treated hyperthyroidism in pregnant women with GD $(5,49,50,51)$. Thus, it has been consistently shown that women who remained overtly hyperthyroid in pregnancy had a higher risk of pregnancy loss, preterm birth, low birth weight of the child, preeclampsia, and maternal heart failure. These early observations have later been corroborated in large observational studies including nonexposed controlled groups $(52,53,54)$. On the other hand, subclinical hyperthyroidism has not been associated with a risk of pregnancy complications and no recommendation of treating this entity is proposed in clinical guidelines (55).

It remains a pertinent question how the thyroid autoimmunity itself, via the presence of TRAb in GD patients, potentially affects the outcome of a pregnancy. A main clinical focus regarding TRAb exists in the second half of pregnancy after the onset of fetal thyroid hormone production, which introduces the risk of fetal and neonatal hyperthyroidism caused by TRAb from the mother. However, the distinct roles of high maternal thyroid hormone levels as compared to high levels of $\mathrm{TRAb}$ remain to be elucidated concerning pregnancy complications and the hypothesis of fetal programming.

\section{Antithyroid drug treatment}

Another determinant considering outcomes of maternal hyperthyroidism in pregnancy is potential side effects to the treatment. As recently reviewed in detail, a major focus and concern is on the risk of teratogenic side effects with the use of ATDs in early pregnancy (56). This focus has emerged from a series of large, observational studies published in the 2010s that reported a risk of birth defects after early pregnancy exposure to Methimazole (MMI), and lately also after Propylthiouracil (PTU). However, the pattern and severity of malformations strikingly differed between MMI and PTU exposure with the most severe malformations observed after early pregnancy treatment MMI. Thus, the recommendation is to use PTU in early pregnancy and to shift from MMI to PTU already when pregnancy is planned or as soon as it is detected $(1,2)$.

Even when several large observational studies point toward an association, one may yet speculate on the underlying mechanisms and determinants of causality. Only few studies so far included data to evaluate the existence of a biological gradient from the dose of the drug, but a large study from Korea showed that a higher cumulative dose of MMI was associated with a higher risk of birth defects (57). Further clues to causal determinants may arise from experimental evidence (10). Thus, we searched for experimental studies that investigated the risk of malformations after prenatal exposure to ATDs. We identified four studies (Table 3)

Table 2 Experimental studies on hyperthyroidism in pregnancy and development of other organs in the offspring.

\begin{tabular}{|c|c|c|c|}
\hline Author & Year & Animal & $\begin{array}{l}\text { Induction of } \\
\text { hyperthyroidism }\end{array}$ \\
\hline $\begin{array}{c}\text { Ariyaratne } \\
\text { et al. (39) }\end{array}$ & 2000 & Rats & s.c. injection (T3) \\
\hline $\begin{array}{l}\text { Chattergoon } \\
\text { et al. (40) }\end{array}$ & 2012 & Sheep & $\begin{array}{l}\text { Added to growth } \\
\text { media (T3) }\end{array}$ \\
\hline Lino et al. (41) & 2014 & Rats & $\begin{array}{l}\text { Added to drinking } \\
\text { water (T4) }\end{array}$ \\
\hline Lino et al. (42) & 2015 & Rats & $\begin{array}{l}\text { Added to drinking } \\
\text { water (T4) }\end{array}$ \\
\hline Karaca et al. (43) & 2015 & Rats & s.c. injection (T4) \\
\hline Maia et al. (44) & 2016 & Rats & $\begin{array}{l}\text { Orogastric } \\
\text { administration (T4) }\end{array}$ \\
\hline Ribeiro et al. (45) & 2018 & Rats & $\begin{array}{l}\text { Orogastric } \\
\text { administration (T4) }\end{array}$ \\
\hline
\end{tabular}

\begin{tabular}{l} 
Outcome \\
assessment \\
\hline Postnatal days \\
$7-21$ \\
Gestational day \\
100 \\
Gestational days \\
18 and 20 \\
Postnatal day 90 \\
Gestational day 20 \\
Postnatal days 0 , \\
21,42 \\
Postnatal days 0 \\
and 20 \\
P
\end{tabular}

\section{Findings in the offspring}

Increased differentiation of adult Leydig cells in testis

Suppressed mitotic activity in cardiomyocytes

Cardiac hypertrophy and altered expression of cardiac reninangiotensin system components Altered expression of cardiac reninangiotensin system components and worse recovery after ischemic insult

Higher expression of vascular endothelial growth factor and increased angiogenesis and apoptosis

Reversible reduced growth and reversible increased percentage of trabecular bone tissue

Reduced endochondral bone growth and reduced proliferation rate in the cartilage https://ec.bioscientifica.com https://doi.org/10.1530/EC-20-0518 (c) 2021 The authors Published by Bioscientifica Ltd
This work is licensed under a Creative Commons Attribution-NonCommercial-NoDerivatives 4.0 International License.ifica com at $04 / 26 / 2023$ 08:47:59AM 
Table 3 Experimental studies on antithyroid drug exposure in pregnancy and outcomes in the offspring.

\begin{tabular}{|c|c|c|c|c|}
\hline Author & Year & Animal & Antithyroid drug & $\begin{array}{l}\text { Outcome } \\
\text { assessment }\end{array}$ \\
\hline $\begin{array}{l}\text { Stanisstreet } \\
\text { et al. (58) }\end{array}$ & 1990 & Rats & $\mathrm{MMI}$ & Gestational day 9.5 \\
\hline $\begin{array}{l}\text { Benavides } \\
\text { et al. (59) }\end{array}$ & 2012 & Mice & MMI and PTU & $\begin{array}{c}\text { Gestational day } \\
10.5 \text { and } 18.5\end{array}$ \\
\hline $\begin{array}{l}\text { Veenendaal } \\
\text { et al. (60) }\end{array}$ & 2013 & Frogs & MMI and PTU & $\begin{array}{l}\text { Nieuwkoop and } \\
\text { Faber stage } 45\end{array}$ \\
\hline Mallela et al. (61) & 2014 & $\begin{array}{l}\text { Mice and } \\
\text { rats }\end{array}$ & MMI and PTU & $\begin{array}{l}\text { Gestational } \\
\text { day } 18 \text { or } 20\end{array}$ \\
\hline
\end{tabular}

Findings in the offspring

MMI was associated with abnormal development of rat embryos in vitro; more severely at higher concentrations

PTU, but not MMI, was associated with neural tube and cardiac defects as well as fetal loss PTU, but not MMI, was associated with cardiac and gut looping defects, abnormal ciliary function and abnormal expression of genes involved in left-right symmetry

PTU and MMI were not associated with histopathological abnormalities or external gross malformations

MMI, methimazole; PTU, propylthiouracil.

that investigated this exposure and outcomes in rats, mice, and frogs $(58,59,60,61)$. Notably, the findings were diverse and in contrast to the findings in humans. Thus, in an experimental setting, MMI revealed adverse outcomes in the offspring in one of the four studies, whereas PTU associated with birth defects in the offspring in two of the three studies that examined this type of drug exposure (Table 3). We can only speculate on possible explanations for this disparity between experimental and human findings. Considering the types of malformations observed in humans after exposure to ATDs (56), it may be speculated that the less severe malformations seen after PTU exposure are not detectable in the rat (e.g. preauricular sinus) and similarly with some of the malformations observed after MMI exposure (e.g. aplasia cutis). Furthermore, the morphological differences between the human and the rat placenta mentioned previously may influence the evaluation of toxicological effects (31). Rate of organ development in different animals and in comparison with humans as well as dose dependency may differ and influence the risk of developmental defects. Finally, in human studies it is often difficult to distinguish between the role of hyperthyroidism per se, the treatment, and the thyroid autoimmunity. This may also be the case in experimental animals since the treatment with ATDs may induce hypothyroidism. The opposite may also be the case and could challenge experimental studies on the role of maternal hypothyroidism per se. Thus, maternal hypothyroidism in an experimental animal is typically induced from treatment with ATDs. Consequently, interpretation of the findings is a difficult task in an experimental design as much as in observational human studies.

\section{Concluding remarks}

It has long been recognized that overt hyperthyroidism of GD in pregnant women should be treated to prevent complications (Table 4). This review highlights that evidence on the adverse effects of untreated or insufficiently treated hyperthyroidism is predominantly obtained from early clinical observations. In these reports and subsequent larger observational studies, a higher risk of pregnancy complications has consistently been reported if the disease is left untreated. Thus, it is well-established and in line with current recommendations that the disease should be treated in pregnant women. On the other hand, it is noteworthy that the burden of evidence from experimental studies and from observational human studies on postpartum and long-term outcomes in the offspring is limited as compared to maternal hypothyroidism in pregnancy. The experimental evidence provides some clues on potential adverse effects in the fetus associated with maternal hyperthyroidism, indicating that perhaps the association between maternal thyroid hormone levels in pregnancy and fetal development is u-shaped. Still, many aspects remain unclarified regarding the underlying mechanisms. In experimental animals as well as in humans, difficulties exist on the distinction between the different exposures that constitute parts of the autoimmune entity of GD. Furthermore, methodological aspects on outcome assessment apply to both settings and adds to difficulties in the comparison of experimental and human findings. As discussed, this is apparent from the inconsistency between experimental and human findings considering teratogenic side effects to the use of ATDs. Nevertheless, to inform clinical practice it is crucial to encourage future studies, basic as well as clinical, to address the distinct role of hyperthyroidism per se, the treatment, and the

This work is licensed under a Creative Commons Attribution-NonCommercial-NoDerivatives 4.0 internationad bicense.ifica.com at 04/26/2023 08:47:59AM 
Table 4 Key points and implications for future studies.

\section{Hyperthyroidism in pregnancy}

- Graves' hyperthyroidism is an autoimmune disorder.

- Graves' hyperthyroidism should be treated in pregnant women.

- Untreated Graves' disease is associated with pregnancy complications.

- Hyperthyroidism in pregnancy is less studied than hypothyroidism.

- Experimental studies provide clues on a fetal programming effect.

- Human studies are sparse and provide no definite conclusions.

- The programming role of thyroid autoimmunity is unclarified.

- Teratogenic side effects to antithyroid drugs pose a challenge.

\section{Implications for future studies}

- enhance the understanding of underlying mechanisms

- address the role of hyperthyroidism, treatment, and autoimmunity

- assess different short- and long-term outcomes in the offspring

- consider mechanisms to support the development of new treatments

autoimmunity (Table 4). To move forward from here, it seems crucial to determine the underlying mechanisms by each exposure and potential interaction between and with other maternal characteristics. Such focus can at the same time provide important guidance on potential targets and possibilities for new treatments with less severe side effects.

\section{Declaration of interest}

The authors declare that there is no conflict of interest that could be perceived as prejudicing the impartiality of this review.

\section{Funding}

This research did not receive any specific grant from any funding agency in the public, commercial or not-for-profit sector.

\section{Author contribution statement}

Stine Linding Andersen conceptualized and drafted the manuscript. Stig Andersen critically reviewed and discussed the manuscript.

\section{References}

1 Alexander EK, Pearce EN, Brent GA, Brown RS, Chen H, Dosiou C, Grobman WA, Laurberg P, Lazarus JH, Mandel SJ, et al. 2017 Guidelines of the American Thyroid Association for the diagnosis and management of thyroid disease during pregnancy and the postpartum. Thyroid 201727 315-389. (https://doi.org/10.1089/thy.2016.0457)

2 Kahaly GJ, Bartalena L, Hegedüs L, Leenhardt L, Poppe K \& Pearce SH. 2018 European Thyroid Association guideline for the management of Graves' hyperthyroidism. European Thyroid Journal 20187 167-186. (https://doi.org/10.1159/000490384)

https://ec.bioscientifica.com https://doi.org/10.1530/EC-20-0518
(C) 2021 The authors Published by Bioscientifica Ltd
3 Carle A, Pedersen IB, Knudsen N, Perrild H, Ovesen L, Rasmussen LB \& Laurberg P. Epidemiology of subtypes of hyperthyroidism in Denmark: a population-based study. European Journal of Endocrinology 2011164 801-809. (https://doi.org/10.1530/EJE-10-1155).

4 Davies TF, Andersen S, Latif R, Nagayama Y, Barbesino G, Brito M, Eckstein AK, Stagnaro-Green A \& Kahaly GJ. Graves' disease. Nature Reviews: Disease Primers 20206 52. (https://doi.org/10.1038/s41572020-0184-y)

5 Gardiner-Hill H. Pregnancy complicating simple goitre and Graves's disease. Lancet 1929213 120-124. (https://doi.org/10.1016/S01406736(00)82433-2)

6 Burch HB \& Cooper DS. Anniversary review: antithyroid drug therapy: 70 years later. European Journal of Endocrinology 2018179 R261-R274. (https://doi.org/10.1530/EJE-18-0678)

7 Andersen SL, Carle A, Karmisholt J, Pedersen IB \& Andersen S. Mechanisms in endocrinology: neurodevelopmental disorders in children born to mothers with thyroid dysfunction: evidence of fetal programming? European Journal of Endocrinology 2017177 R27-R36. (https://doi.org/10.1530/EJE-16-0947)

8 David Barker OJ. A giant in reproductive epidemiology. Acta Obstetricia et Gynecologica Scandinavica 2014 1938-2013 93 1077-1080.

9 Stevenson K, Lillycrop KA \& Silver MJ. Fetal programming and epigenetics. Current Opinion in Endocrine and Metabolic Research 2020 13 1-6. (https://doi.org/10.1016/j.coemr.2020.07.005)

10 Hill AB. The environment and disease: association or causation? Proceedings of the Royal Society of Medicine $1965 \mathbf{5 8}$ 295-300. (https:// doi.org/10.1177/003591576505800503)

11 Gudernatsch JF. Feeding experiments on tadpoles. Archiv für Entwicklungsmechanik der Organismen 191235 457-483. (https://doi. org/10.1007/BF02277051).

12 Vulsma T, Gons MH \& Vijlder JJ de. Maternal-fetal transfer of thyroxine in congenital hypothyroidism due to a total organification defect or thyroid agenesis. New England Journal of Medicine $1989 \mathbf{3 2 1}$ 13-16. (https://doi.org/10.1056/NEJM198907063210103)

13 Laurberg P \& Andersen SL. Endocrinology in pregnancy: pregnancy and the incidence, diagnosing and therapy of Graves' disease. European Journal of Endocrinology 2016175 R219-R230. (https://doi. org/10.1530/EJE-16-0410)

14 Alexander EK, Marqusee E, Lawrence J, Jarolim P, Fischer GA \& Larsen PR. Timing and magnitude of increases in levothyroxine requirements during pregnancy in women with hypothyroidism. New England Journal of Medicine 2004351 241-249. (https://doi. org/10.1056/NEJMoa040079)

15 Laurberg P, Andersen SL, Hindersson P, Nohr EA \& Olsen J. Dynamics and predictors of serum TSH and fT4 reference limits in early pregnancy: A study within the Danish national birth cohort. Journal of Clinical Endocrinology and Metabolism $20161012484-2492$. (https://doi.org/10.1210/jc.2016-1387).

16 Jassam N, Visser TJ, Brisco T, Bathia D, McClean P \& Barth JH. Consumptive hypothyroidism: a case report and review of the literature. Annals of Clinical Biochemistry 201148 186-189. (https:// doi.org/10.1258/acb.2010.010170)

17 Lazarus J, Brown RS, Daumerie C, Hubalewska-Dydejczyk A, Negro R \& Vaidya B. 2014 European Thyroid Association guidelines for the management of subclinical hypothyroidism in pregnancy and in children. European Thyroid Journal 20143 76-94. (https://doi. org/10.1159/000362597)

18 Dewey KG \& Oaks BM. U-shaped curve for risk associated with maternal hemoglobin, iron status, or iron supplementation. American Journal of Clinical Nutrition 2017106 1694S-1702S. (https://doi. org/10.3945/ajcn.117.156075)

19 Bernal J \& Nunez J. Thyroid hormones and brain development. European Journal of Endocrinology 1995133 390-398. (https://doi. org/10.1530/eje.0.1330390)

20 Evans IM, Pickard MR, Sinha AK, Leonard AJ, Sampson DC \& Ekins RP. Influence of maternal hyperthyroidism in the rat on the 
expression of neuronal and astrocytic cytoskeletal proteins in fetal brain. Journal of Endocrinology 2002175 597-604. (https://doi. org/10.1677/joe.0.1750597)

21 Zhang L, Hernandez VS, Medina-Pizarro M, Valle-Leija P, VegaGonzalez A \& Morales T. Maternal hyperthyroidism in rats impairs stress coping of adult offspring. Journal of Neuroscience Research 2008 86 1306-1315. (https://doi.org/10.1002/jnr.21580)

22 Zhang L, Medina MP, Hernández VS, Estrada FS \& Vega-González A. Vasopressinergic network abnormalities potentiate conditioned anxious state of rats subjected to maternal hyperthyroidism. Neuroscience 2010168 416-428. (https://doi.org/10.1016/j. neuroscience.2010.03.059)

23 El-bakry AM, El-Gareib AW \& Ahmed RG. Comparative study of the effects of experimentally induced hypothyroidism and hyperthyroidism in some brain regions in albino rats. International Journal of Developmental Neuroscience 201028 371-389. (https://doi. org/10.1016/j.ijdevneu.2010.04.003)

24 Ahmed OM, Abd El-Tawab SM \& Ahmed RG. Effects of experimentally induced maternal hypothyroidism and hyperthyroidism on the development of rat offspring: I. The development of the thyroid hormones-neurotransmitters and adenosinergic system interactions. International Journal of Developmental Neuroscience 201028 437-454. (https://doi.org/10.1016/j.ijdevneu.2010.06.007)

25 Ahmed OM, Ahmed RG, El-Gareib AW, El-Bakry AM \& Abd El-Tawab SM. Effects of experimentally induced maternal hypothyroidism and hyperthyroidism on the development of rat offspring: II-the developmental pattern of neurons in relation to oxidative stress and antioxidant defense system. International Journal of Developmental Neuroscience 201230 517-537. (https://doi. org/10.1016/j.ijdevneu.2012.04.005)

26 Strobl MJ, Freeman D, Patel J, Poulsen R, Wendler CC, Rivkees SA \& Coleman JE. Opposing effects of maternal hypo- and hyperthyroidism on the stability of thalamocortical synapses in the visual cortex of adult offspring. Cerebral Cortex 201727 3015-3027. (https://doi.org/10.1093/cercor/bhw096)

27 Laureano-Melo R, Souza JS, da Conceição RR, Albuquerque JML, Rodrigues NC, Marinho BG, Olivares EL, Giannocco G \& Côrtes WDS. Prenatal thyroxine treatment promotes anxiolysis in male Swiss mice offspring. Hormones and Behavior 2019108 10-19. (https://doi.org/10.1016/j.yhbeh.2018.12.008)

28 Salami M, Bandegi AR, Sameni HR, Vafaei AA \& Pakdel A. Hippocampal up-regulation of apolipoprotein $\mathrm{D}$ in a rat model of maternal hypo- and hyperthyroidism: implication of oxidative stress. Neurochemical Research 201944 2190-2201. (https://doi.org/10.1007/ s11064-019-02859-5)

29 Richard S \& Flamant F. Regulation of T3 availability in the developing brain: the mouse genetics contribution. Frontiers in Endocrinology 2018 9 265. (https://doi.org/10.3389/fendo.2018.00265).

30 Zhang H, Lin S, Chen X, Gu L, Zhu X, Zhang Y, Reyes K, Wang B $\&$ Jin $\mathrm{K}$. The effect of age, sex and strains on the performance and outcome in animal models of stroke. Neurochemistry International 2019127 2-11. (https://doi.org/10.1016/j.neuint.2018.10.005)

31 Furukawa S, Tsuji N \& Sugiyama A. Morphology and physiology of rat placenta for toxicological evaluation. Journal of Toxicologic Pathology 201932 1-17. (https://doi.org/10.1293/tox.2018-0042)

32 Ramhøj L, Hass U, Gilbert ME, Wood C, Svingen T, Usai D, Vinggaard AM, Mandrup K \& Axelstad M. Evaluating thyroid hormone disruption: investigations of long-term neurodevelopmental effects in rats after perinatal exposure to perfluorohexane sulfonate (PFHxS). Scientific Reports 2020102672. (https://doi.org/10.1038/s41598-020-59354-z)

33 Andersen SL, Andersen S, Liew Z, Vestergaard P \& Olsen J. Maternal thyroid function in early pregnancy and neuropsychological performance of the child at 5 years of age. Journal of Clinical Endocrinology and Metabolism 2018103 660-670. (https://doi. org/10.1210/jc.2017-02171)
34 Jansen TA, Korevaar TIM, Mulder TA, White T, Muetzel RL, Peeters RP \& Tiemeier H. Maternal thyroid function during pregnancy and child brain morphology: a time window-specific analysis of a prospective cohort. Lancet: Diabetes and Endocrinology 20197 629-637. (https:// doi.org/10.1016/S2213-8587(19)30153-6)

35 Ge GM, Leung MTY, Man KKC, Leung WC, Ip P, Li GHY, Wong ICK, Kung AWC \& Cheung CL. Maternal thyroid dysfunction during pregnancy and the risk of adverse outcomes in the offspring: a systematic review and meta-analysis. Journal of Clinical Endocrinology and Metabolism 2020105 1-21. (https://doi.org/10.1210/clinem/dgaa555)

36 Andersen SL, Andersen S, Vestergaard P \& Olsen J. Maternal thyroid function in early pregnancy and child neurodevelopmental disorders: a Danish nationwide case-cohort study. Thyroid 201828 537-546. (https://doi.org/10.1089/thy.2017.0425)

37 Hauser P, Zametkin AJ, Martinez P, Vitiello B, Matochik JA, Mixson AJ $\&$ Weintraub BD. Attention deficit-hyperactivity disorder in people with generalized resistance to thyroid hormone. New England Journal of Medicine 1993328 997-1001. (https://doi.org/10.1056/ NEJM199304083281403)

38 Srichomkwun P, Anselmo J, Liao XH, Hönes GS, Moeller LC, AlonsoSampedro M, Weiss RE, Dumitrescu AM \& Refetoff S. Fetal exposure to high maternal thyroid hormone levels causes central resistance to thyroid hormone in adult humans and mice. Journal of Clinical Endocrinology and Metabolism 2017102 3234-3240. (https://doi. org/10.1210/jc.2017-00019)

39 Siril Ariyaratne HB, Chamindrani Mendis-Handagama S, Buchanan Hales D \& Ian Mason J. Studies on the onset of Leydig precursor cell differentiation in the prepubertal rat testis. Biology of Reproduction 200063 165-171. (https://doi.org/10.1095/biolreprod63.1.165)

40 Chattergoon NN, Louey S, Stork P, Giraud GD \& Thornburg KL. Midgestation ovine cardiomyocytes are vulnerable to mitotic suppression by thyroid hormone. Reproductive Sciences 201219 642-649. (https:// doi.org/10.1177/1933719111432860)

41 Lino CA, Shibata CER \& Barreto-Chaves MLM. Maternal hyperthyroidism alters the pattern of expression of cardiac reninangiotensin system components in rat offspring. Journal of the Renin-Angiotensin-Aldosterone System 201415 52-60. (https://doi. org/10.1177/1470320312470581)

42 Lino CA, Silva IB da, Shibata CER, Monteiro Pde S \& BarretoChaves MLM. Maternal hyperthyroidism increases the susceptibility of rat adult offspring to cardiovascular disorders. Molecular and Cellular Endocrinology 2015416 1-8. (https://doi.org/10.1016/j. mce.2015.08.015)

43 Karaca T, Hulya Uz Y, Karabacak R, Karaboga I, Demirtas S \& Cagatay Cicek A. Effects of hyperthyroidism on expression of vascular endothelial growth factor (VEGF) and apoptosis in fetal adrenal glands. European Journal of Histochemistry 201559 2560. (https://doi org/10.4081/ejh.2015.2560)

44 Maia MZ, Santos GK, Batista ACM, Reis AMS, Silva JF, Ribeiro LGR, Ocarino Nde M \& Serakides R. Effects of excess maternal thyroxin on the bones of rat offspring from birth to the post-weaning period. Archives of Endocrinology and Metabolism $2016 \mathbf{6 0}$ 130-137. (https:// doi.org/10.1590/2359-3997000000168)

45 Ribeiro LGR, Silva JF, Ocarino NM, Souza CA, Melo EG \& Serakides R. Excess maternal thyroxine alters the proliferative activity and angiogenic profile of growth cartilage of rats at birth and weaning. Cartilage 20189 89-103. (https://doi. org/10.1177/1947603516684587)

46 Godoy GA, Korevaar TI, Peeters RP, Hofman A, Rijke YB de, Bongers-Schokking JJ, Tiemeier H, Jaddoe VW \& Gaillard R. Maternal thyroid hormones during pregnancy, childhood adiposity and cardiovascular risk factors: the Generation R Study. Clinical Endocrinology 201481 117-125. (https://doi.org/10.1111/ cen.12399)

47 Rytter D, Andersen SL, Bech BH, Halldorsson TI, Henriksen TB, Laurberg P \& Olsen SF. Maternal thyroid function in pregnancy may 
program offspring blood pressure, but not adiposity at $20 \mathrm{y}$ of age. Pediatric Research 201680 7-13. (https://doi.org/10.1038/pr.2016.56)

48 Andersen SL, Andersen S, Liew Z, Vestergaard P, LundbyeChristensen S, Sørensen TIA \& Olsen J. Maternal thyroid disease and adiposity in mother and child. Clinical Endocrinology 2020 [epub]. (https://doi.org/10.1111/cen.14314)

49 Piper J \& Rosen J. Management of hyperthyroidism during pregnancy. Acta Medica Scandinavica 1954150 215-222. (https://doi. org/10.1111/j.0954-6820.1954.tb18620.x)

50 Davis LE, Lucas MJ, Hankins GD, Roark ML \& Cunningham FG. Thyrotoxicosis complicating pregnancy. American Journal of Obstetrics and Gynecology 1989160 63-70. (https://doi.org/10.1016/00029378(89)90088-4)

51 Millar LK, Wing DA, Leung AS, Koonings PP, Montoro MN \& Mestman JH. Low birth weight and preeclampsia in pregnancies complicated by hyperthyroidism. Obstetrics and Gynecology 199484 946-949.

52 Andersen SL, Olsen J, Wu CS \& Laurberg P. Low birth weight in children born to mothers with hyperthyroidism and high birth weight in hypothyroidism, whereas preterm birth is common in both conditions: a Danish National Hospital Register study. European Thyroid Journal 20132 135-144. (https://doi.org/10.1159/000350513)

53 Andersen SL, Olsen J, Wu CS \& Laurberg P. Spontaneous abortion, stillbirth and hyperthyroidism: a Danish population-based study. European Thyroid Journal 20143 164-172. (https://doi. org/10.1159/000365101)

54 Turunen S, Vääräsmäki M, Lahesmaa-Korpinen AM, Leinonen MK, Gissler M, Männistö T \& Suvanto E. Maternal hyperthyroidism and pregnancy outcomes: a population-based cohort study. Clinical Endocrinology 202093 721-728. (https://doi.org/10.1111/cen.14282)

55 Casey BM, Dashe JS, Wells CE, McIntire DD, Leveno KJ \& Cunningham FG. Subclinical hyperthyroidism and pregnancy outcomes. Obstetrics and Gynecology 2006107 337-341. (https://doi. org/10.1097/01.AOG.0000197991.64246.9a)

56 Andersen SL \& Andersen S. Antithyroid drugs and birth defects. Thyroid Research 202013 11. (https://doi.org/10.1186/s13044-020-00085-8)

57 Seo GH, Kim TH \& Chung JH. Antithyroid drugs and congenital malformations: a nationwide Korean cohort study. Annals of Internal Medicine 2018168 405-413. (https://doi.org/10.7326/ M17-1398).

58 Stanisstreet M, Herbert LC \& Pharoah PO. Effects of thyroid antagonists on rat embryos cultured in vitro. Teratology $1990 \mathbf{4 1}$ 721-729. (https://doi.org/10.1002/tera.1420410609)

59 Benavides VC, Mallela MK, Booth CJ, Wendler CC \& Rivkees SA. Propylthiouracil is teratogenic in murine embryos. PLoS ONE 20127 e35213. (https://doi.org/10.1371/journal.pone.0035213)

60 Veenendaal NR van, Ulmer B, Boskovski MT, Fang X, Khokha MK, Wendler CC, Blum M \& Rivkees SA. Embryonic exposure to propylthiouracil disrupts left-right patterning in Xenopus embryos. FASEB Journal 201327 684-691. (https://doi.org/10.1096/fj.12218073)

61 Mallela MK, Strobl M, Poulsen RR, Wendler CC, Booth CJ \& Rivkees SA. Evaluation of developmental toxicity of propylthiouracil and methimazole. Birth Defects Research: Part B, Developmental and Reproductive Toxicology 2014101 300-307. (https://doi.org/10.1002/ bdrb.21113)

Received in final form 4 December 2020

Accepted 6 January 2021

Accepted manuscript published online 8 January 2021 (c) 2021 The authors Published by Bioscientifica Ltd
This work is licensed under a Creative Commons Attribution-NonCommercial-NoDerivatives 4.0 Internationab bicense.ifica . com at $04 / 26 / 2023 \quad 08: 47: 59 \mathrm{Am}$ 